DYSLEXIA:

FROM THEORY TO INTERVENTION 


\section{NEUROPSYCHOLOGY AND COGNITION}

\section{VOLUME 18}

Series Editor:

R. Malatesha Joshi, Oklahoma State University, U.S.A.

Advisory Board:

Alfonso Caramazza, The Johns Hopkins University, U.S.A.

George Hynd, University of Georgia, U.S.A.

C.K. Leong, University of Saskatchewan, Canada

John Marshall, University of Oxford, U.K.

Gabriele Miceli, Università Cattolica Del Sacro Cuore, Italy

Loraine Obler, City University of New York, U.S.A.

Sandra Witelson, McMaster University, Canada

The purpose of the Neuropsychology and Cognition series is to bring out volumes that promote understanding in topics relating brain and behavior. It is intended for use by both clinicians and research scientists in the fields of neuropsychology, cognitive psychology, psycholinguistics, speech and hearing, as well as education. Examples of topics to be covered in the series would relate to memory, language acquisition and breakdown, reading, attention, developing and aging brain. By addressing the theoretical, empirical, and applied aspects of brain-behavior relationships, this series will try to present the information in the fields of neuropsychology and cognition in a coherent manner.

The titles published in this series are listed at the end of this volume. 


\title{
DYSLEXIA: FROM THEORY TO INTERVENTION
}

\author{
by \\ TORLEIV HØIEN \\ Dyslexia Research Foundation, \\ Stavanger, Norway \\ and \\ INGVAR LUNDBERG \\ Department of Psychology, \\ Göteborg University, Sweden
}

SPRINGER-SCIENCE+BUSINESS MEDIA, B.V . 
Library of Congress Cataloging-in-Publication Data.

ISBN 978-90-481-5457-9 ISBN 978-94-017-1329-0 (eBook)

DOI 10.1007/978-94-017-1329-0

This volume is a translation from Dysleksi: Fra Teori til Praksis edited by T. Høien and I. Lundberg.

Published by Ad Notam Gyldendal, 1997

Printed on acid-free paper

All Rights Reserved

(C) 2000 Springer Science+Business Media Dordrecht

Originally published by Kluwer Academic Publishers in 2000

Softcover reprint of the hardcover 1st edition 2000

No part of the material protected by this copyright notice may be reproduced or utilized in any form or by any means, electronic or mechanical, including photocopying, recording or by any information storage and retrieval system, without written permission from the copyright owner. 


\section{TABLE OF CONTENTS}

PREFACE $\quad x i$

CHAPTER 1. WHAT IS DYSLEXIA?

The problem of definition 3

Reading is both decoding and comprehension $\quad 4$

A new American working definition $\quad 7$

Our definiton of dyslexia $\quad 8$

Subgroups of dyslexia 11

Empirical research and the subgrouping of dyslexics 12

From subgrouping to diagnosing, based on a model of reading $\quad 14$

$\begin{array}{ll}\text { Methods in dyslexia research } & 16\end{array}$

Case studies 16

Comparing dyslexics with age-matched normal readers $\quad 17$

$\begin{array}{ll}\text { Matching by reading level } & 17\end{array}$

$\begin{array}{ll}\text { Longitudinal studies } & 18\end{array}$

Experimental studies $\quad 18$

Recent techniques $\quad 19$

$\begin{array}{ll}\text { Brief summary } & 19\end{array}$

CHAPTER 2. DECODING DIFFICULTIES -

A MAJOR SYMPTOM OF DYSLEXIA 21

Decoding strategies $\quad 22$

$\begin{array}{ll}\text { Stages of reading development } & 24\end{array}$

Pseudo-reading 25

The logographic-visual stage $\quad 26$

The alphabetic-phonemic stage $\quad 28$

The orthographic-morphemic stage $\quad 30$

Context and Word recognition 31

A model of word decoding $\quad 32$

Perceptual processes $\quad 36$

The sensory process $\quad 36$

Visual analysis (VA) $\quad 41$

Letter recognition process (LR) 43 
$\begin{array}{ll}\text { Linguistic processes } & 44\end{array}$

Parsing (P) 44

Word recognition process (OWR1) 45

Semantic activation (SA) $\quad 46$

Phonological word retrieval (PhWR2) 46

The articulation process (AP) $\quad 47$

Prelexical phonological recoding (PhR) 47

Verbal short-term memory (STM) 49

Phonological synthesis (PhS) 49

Objections to dual-route models $\quad 49$

Connectionistic theory - an alternative to dual-route models $\quad 50$

Decoding strategies used by dyslexics 51

Phonological difficulties: Delayed maturation or a specific deficit? $\quad 52$

Problems in automatization $\quad 53$

Brief summary $\quad 54$

CHAPTER 3. SPELLING DIFFICULTY:

A MAJOR SYMPTOM OF DYSLEXIA 55

Stages in the development of spelling $\quad 56$

Pseudo-spelling $\quad 56$

Logographic-visual spelling $\quad 56$

Alphabetic-phonemic spelling $\quad 57$

Orthographic-morphemic spelling $\quad 59$

$\begin{array}{ll}\text { Types of spelling errors } & 60\end{array}$

Errors of knowledge $\quad 60$

Errors in performance 61

Analysis of errors $\quad 61$

$\begin{array}{ll}\text { Spelling and speaking } & 62\end{array}$

Spelling and reading $\quad 63$

Spelling errors and the definition of dyslexia $\quad 64$

Spelling errors and subgroups of dyslexia 66

$\begin{array}{ll}\text { Handwriting } & 67\end{array}$

$\begin{array}{ll}\text { Spelling strategies } & 68\end{array}$

Spelling strategies and linguistic aspects of words $\quad 70$

Auxiliary strategies $\quad 70$

A model of the spelling process $\quad 72$

Spelling of a dictated word with a familiar spelling 73

Spelling of a dictated word with an unfamiliar spelling $\quad 74$

Spelling of dictated nonwords $\quad 76$

Writing non-dictated words $\quad 78$

$\begin{array}{ll}\text { The writing process } & 79\end{array}$

Brief summary $\quad 81$ 
$\begin{array}{ll}\text { Can reading and writing problems be predicted in preschoolers? } & 87\end{array}$

$\begin{array}{ll}\text { The problem of identifying at-risk children } & 88\end{array}$

$\begin{array}{ll}\text { A longitudinal study } & 90\end{array}$

Phonological problems among older dyslexic children 91

Compensating for the specific deficit $\quad 94$

Can phonological stimulation prevent dyslexia? 95

How did the at-risk children fare? $\quad 96$

$\begin{array}{ll}\text { Brief summary } & 100\end{array}$

CHAPTER 5. DYSLEXIA AND READING COMPREHENSION 101

$\begin{array}{ll}\text { Reading comprehension } & 102\end{array}$

Vocabulary 102

Knowledge of the world 103

Metacognition 106

Metacognition when learning to read $\quad 106$

$\begin{array}{ll}\text { Reading comprehension and metacognition } & 107\end{array}$

$\begin{array}{ll}\text { Reading strategies } & 109\end{array}$

Brief summary $\quad 113$

CHAPTER 6. THE BIOLOGICAL BASIS OF DYSLEXIA 115

Dyslexia and the brain 115

Structure of the brain 115

Studies of brain structure $\quad 118$

The planum temporale symmetry and dyslexia $\quad 119$

Corpus callosum and dyslexia $\quad 122$

Cell structure and dyslexia $\quad 123$

The cerebellum and dyslexia $\quad 125$

$\begin{array}{ll}\text { The brain in action } & 127\end{array}$

Is the brain activity different in dyslexics? 129

Dyslexia and other biologically-based disturbances 131

Dyslexia and inheritance 131

The most important arguments in support of genetic basis of dyslexia 133

Recent results of research 137

$\begin{array}{ll}\text { Brief summary } & 137\end{array}$

CHAPTER 7. ASSESSMENT AND DIAGNOSING 139

An approach based on process analysis $\quad 141$ 
Assessment of word decoding problems 143

Strategies in decoding single words 143

Assessment of strategy skill $\quad 145$

Assessment of the orthographic strategy 146

$\begin{array}{ll}\text { Assessment of the phonological strategy } & 147\end{array}$

Analysis of errors $\quad 148$

$\begin{array}{ll}\text { KOAS } & 149\end{array}$

Assessment of word decoding processes $\quad 150$

Word chain test 151

Assessment of reading text aloud $\quad 152$

Assessment of spelling $\quad 152$

Which words are difficult to spell correctly? 153

Analysis of spelling mistakes $\quad 153$

$\begin{array}{ll}\text { Assessment of written work } & 154\end{array}$

Assessment of phonological problems $\quad 155$

$\begin{array}{lr}\text { Assessment of morphological awareness } & 157\end{array}$

Assessment of reading comprehension $\quad 158$

Assessment of metacognition $\quad 158$

Assessing obstacles to good reading $\quad 159$

$\begin{array}{ll}\text { Poor intellectual ability } & 160\end{array}$

Delayed language development $\quad 160$

$\begin{array}{ll}\text { Visual deficits } & 161\end{array}$

Impaired hearing $\quad 161$

Emotional and motivational problems $\quad 162$

Home environment 164

Insufficient instruction $\quad 165$

$\begin{array}{ll}\text { Diagnosis of adult dyslexics } & 166\end{array}$

$\begin{array}{ll}\text { Brief summary } & 167\end{array}$

$\begin{array}{ll}\text { CHAPTER 8. REMEDIATION } & 169\end{array}$

$\begin{array}{ll}\text { Problems when evaluating remediation } & 169\end{array}$

$\begin{array}{ll}\text { General principles of educational remediation in dyslexics } & 171\end{array}$

$\begin{array}{ll}\text { Remediation to promote decoding skill } & 179\end{array}$

$\begin{array}{ll}\text { Learning reliable knowledge of letters } & 179\end{array}$

$\begin{array}{ll}\text { Learning reliable associations between orthographic } & 179 \\ \text { and phonological units } & 180\end{array}$

Learning reliable and automatic word decoding $\quad 180$

A combination of sound method and whole word method 181

Technical aids that can be used to promote reading skill 181

Books with cassettes 181

Computer-based training $\quad 182$

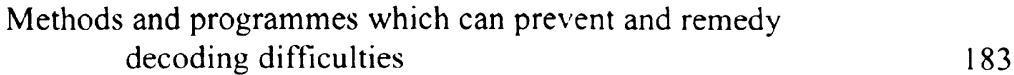

Fernald's VAKT method 183 
The Orton/Gillingham/Stillman method

The Lindamood Auditory Discrimination in

Depth programme

The Reading Recovery programme $\quad 184$

The Early Steps programme $\quad 185$

$\begin{array}{ll}\text { Measures to promote reading comprehension } & 188\end{array}$

Learning new words $\quad 188$

$\begin{array}{ll}\text { Background knowledge } & 189\end{array}$

The grammar and metacognition of the story $\quad 190$

Programmes for promoting reading comprehension 190

$\begin{array}{ll}\text { Explicit instruction } & 190\end{array}$

Reciprocal instruction 191

The CRISS programme 191

Measures for children with writing difficulties $\quad 192$

Spelling $\quad 192$

Use of word processing programmes 193

$\begin{array}{ll}\text { Preparing appropriate texts for the dyslexic } & 194\end{array}$

$\begin{array}{ll}\text { The linguistic formulation of texts } & 195\end{array}$

$\begin{array}{ll}\text { Choice of reading texts for the dyslexic } & 197\end{array}$

Emphasizing strong sides of dyslexics $\quad 198$

Alternative methods $\quad 199$

Prognosis for pupils with dyslexia $\quad 199$

Conclusion and comments 200

Brief summary 201

$\begin{array}{ll}\text { REFERENCES } & 203\end{array}$

$\begin{array}{ll}\text { AUTHOR INDEX } & 221\end{array}$

$\begin{array}{ll}\text { SUBJECT INDEX } & 227\end{array}$ 


\section{PREFACE}

By the end of the 1980's dyslexia research had come of age in many countries, perhaps most particularly in the Nordic countries. Part of the impetus for the research was a growing need on the part of special teachers, school psychologists and others for solid, verified knowledge about reading and writing problems. In the decades leading up to the 1980's, it had become increasingly clear that individuals who couldn't efficiently deal with written language had an enormous handicap, because the demands society and the work market made on literacy had increased so greatly. The number of young people who continued in school past the obligatory years also increased dramatically, and this made the problem of dyslexia especially obvious. Our first book together on dyslexia, which was published in Norwegian in 1991, came to fill an important role. It was soon translated into Swedish and Danish, and it was used as a textbook at a great many colleges and universities throughout the Nordic countries.

But science rarely stands still. Since our book was published, a veritable tidalwave of new studies have been published in a growing number of journals or presented at international conferences. Our knowledge of dyslexia has expanded in breadth and depth the last ten years. The cross-disciplinary and multidisciplinary nature of reading research has become ever clearer. Neurobiology has made great advances in imaging techniques, allowing us to peer into the brains of living, thinking people. Molecular genetics is well on its way to demonstrating how a propensity for dyslexia is inherited. The fields of psychology and linguistics have increased our understanding of what language is and how children acquire and develop language skills, topics of direct relevance to the study of dyslexia. Better methods for diagnosing and remediating the condition have also been developed. In the field of education we see several new and promising approaches entailing early intervention and prevention in the pre-school years. Personal computers, perhaps the icon of the 1990's, are being increasingly often used for training reading and writing skills, and also to help compensate for the lack of those skills.

Because of a great many inquiries from scholars in many countries, we were persuaded to publish an English-language version of our book from 1997. The present book is, we hope, not merely a translation of our book, but a fairly thorough reworking of it with an eye to communicating with the international community of scholars. Dyslexia is not confined to any one language group. Any society with an alphabetical language (and that includes of course all the societies in Europe) will be marked by the condition. The problems dyslexic children in Finland, Greece, or the U.S. have are fundamentally the same, even though there may be some variation in how they are expressed, due to variation in the regularity of spelling in the 
languages in question. But fundamentally the problems and the condition are the same. Therefore, good research conducted in, say, Denmark, is immediately relevant to conditions in the U.S. or Great Britain. But, sadly, much good Scandinavian research has not been readily available to scholars who are unfamiliar with these languages.

Not only has our knowledge of dyslexia gained in breadth and depth the last ten years or so; it has to a certain measure also acquired an additional focus. Sociologists and others have contributed studies of the societal conditions that create and maintain the handicap, and the social constructions which constitute a concept like dyslexia. New perspectives on knowledge, teachers, and pupils have come to the fore, and at the same time we find a growing interest in qualitative methods in the behavioural sciences. Among other things, these qualitative methods grant us a more complete view of the disorder, by allowing dyslexics to tell us about their experiences. To a certain degree we have tried to reflect these new perspectives in the present book, and we acknowledge the value a social view of dyslexia can provide, in addition to the traditional medical and individual-oriented perspective.

The rapid pace of scientific advancement, and the pace of social change in general, provide ample reason for a new book about an old problem. Of course, while we have tried to provide a fairly complete picture of the status of our knowledge and theories today, we know full well that it is impossible to present in a single volume more than a selection of facts and theories. We have tried to eschew the trendy theories that come and go and the undocumented factoids that play well in the media, and we have tried instead to focus on research results that would seem to have a long shelf-life and that have been verified in many different studies.

Research in the last decade has provided more and more support for the hypothesis that (1) dyslexia is first and foremost a problem in decoding written words, or a problem in quickly and accurately identifying written words, and (2) that this problem is rooted in a deficit in the pupil's phonological system (his/her ability to deal with language-sounds). Because this view has been confirmed in a great many studies, it forms the backbone of the present book. But we are nonetheless open for other explanations of reading problems, such as general problems in automaticity and problems in recognizing visual patterns. Both of these alternative explanations are treated in this book. But the theoretical model we have based much of our work on grants special status to the reader's phonological system. (This model, incidentally, is virtually the same as the model we first presented in our book in 1991.)

There is nothing more practical than a good theory, as an old saying would have it. We believe that the myriad of practical problems encountered in diagnosing and treating reading problems become easier to deal with when you have a deep, theoretical understanding of the condition and its etiology. Nevertheless, no child has ever been helped by the teacher's theory alone. True learning can only take place in an environment imbued with mutual respect.

Preface comes first, but is written last, thus giving us the chance to express our indebtedness to our many friends, colleagues, and students who through the years have provided us with so many constructive criticisms and shared so many insights with us. To them all: thank you. In particular we would like to thank our 
secretary, Jette Marie Harbo, whose patience and editorial talent we have profited greatly from. We are also greatly indebted to our translators, Michael Evans (chapters 1-4) and Susan Schanche (chapters 5-8). Michael Evans also served as our chief translator and adaptor, to whom we owe many of the English spelling and phonological examples in the early chapters.

Stavanger, Norway, January 2000

Torleiv Høien and Ingvar Lundberg 